\title{
Drug-trafficking as a Non-traditional Security Threat: Emerging Trends and Responses
}

\author{
Pushpita Das*
}

\begin{abstract}
India's proximity to two of the world's largest producers of opium and synthetic drugs and its large pharmaceutical base has made the country not only a conduit but also a source for drug trafficking. This illegal movement of narcotics and drugs pose significant threats to national security: breach of security of the international borders and the country, money generated by the sale of drugs and narcotics are used for terror funding and criminal groups engaged in drug trafficking develop nexus with terror networks. The trends and patterns of drug trafficking in the country demonstrate that there has been a gradual shift from traditional/natural drugs towards synthetic drugs that are being trafficked and consumed in the country. The paper analyses the steps taken by the State to curb the process and its effectiveness so far.
\end{abstract}

Keywords: Drug Trafficking, National Security, Borders, Terror Funding, Anti-Drug Laws

\section{Introduction}

While India has been facing the menace of drug trafficking for several decades, the problem has become acute in the past several years. The proximity of the country to two of the world's largest opium-producing areas- the golden crescent and the golden

\footnotetext{
* Institute for Defence Studies and Analyses (IDSA), New Delhi, India; pushpitad@yahoo.com
} 
triangle has made India a conduit as well as a destination for the narcotics and synthetic drugs produced there. India is also one of the licit cultivators of poppy and producer of opium gum for medicinal purposes. Poppy is cultivated in select tracts in Madhya Pradesh, Uttar Pradesh, and Rajasthan under license(Licit Cultivation, 2016). Unfortunately, a portion of this poppy is illegally diverted to prepare low-grade heroin called brown sugar. Brown sugar is also manufactured from poppy illegally cultivated in various parts of the country. These are then trafficked inside as well as outside India into the neighbouring countries. In addition, India has a huge pharmaceutical industrial base and manufactures a wide variety of medicinal and synthetic drugs as well as precursor chemicals. As a result, it has become a substantial source for drugs especially prescription drugs and precursor chemicals used for manufacturing heroin and methamphetamine, which are smuggled out of the country.

\subsection{A Threat to National Security}

This two-way illegal movement of narcotics and drugs pose a significant threat to national security. For one, it results in a breach of the international borders of the country by drug traffickers. The breach is a serious issue on two accounts. Firstly, it raises questions about the capability of the Indian states to effectively control its borders and protect its citizens from external threats. Secondly, the fact that drug peddlers could smuggle in illegal or controlled substances through the borders with ease implies that that the same routes could be used by them for smuggling in arms, explosives as well as terrorists into the country. In fact, it has been established that the arms and explosives used in the 1993 serial bomb blasts in Mumbai were transported by the Dawood Ibrahim gang through the routes traditionally used by them for smuggling narcotics and drugs into the country (Central Administrative Tribunal, n.d) Investigations into the Pathankot attack that took place on $31^{\text {st }}$ December 2015 also hinted that the terrorists entered into India from Pakistan through the routes tried and tested by drug traffickers (Unnithan, 2016).

Secondly, the money generated by the illegal sale of narcotics drugs is used to finance terrorist activities. In the past, Afghani opium 
and opium-based drugs were supplied by Taliban drug lords and funded the Taliban insurgency in Afghanistan (The New York Times, 2016). In Columbia, illegal production and sale of cocaine have been a major source of finance for the Revolutionary Armed Forces of Columbia (FARC) to finance their insurgency in that country. Earlier the FARC would tax drug producers and smugglers, but later on, they started cultivating and selling cocaine which enabled them to buy sophisticated weapons as well as recruit and pay large numbers of cadres (Otis, 2014). Back home, the Kashmiri, Sikh and Northeast militants have used drug money to finance and sustain their struggle against the Indian state. It is estimated that 15 percent of the finances of the J\&K militants were generated through the sale of drugs (Jamwal, 2001). In the Northeast, the smaller militant organisations such as the Kangleipak Communist Party are directly involved in drug trafficking to generate quick funds for their organisations (Shivananda. H, 2011). The bigger organisations such as the NSCN etc., however, are believed not to be directly involved in the drug trade but collect protection money from the drug peddlers in exchange for safe passage of drug consignments throgh their territory.

Third, the nexus between drug traffickers, criminal networks and terrorists is yet another potential threat. In the past, criminal groups engaged in drug trafficking such as the Dawood Ibrahim gang had resorted to terrorist acts. The linkages that the Dawood Ibrahim group forged with Pakistani criminal groups as well as with Pakistani state actors who were suspected to be involved in drug smuggling facilitated it to carry out the 1993 serial bomb blasts in Mumbai. The arsenal was sourced from Pakistan and those who took part in the blasts were also trained in Pakistan (Kalyanaraman, 2010). After that incident, the D company was not involved in any other terrorist attack, but it was actively involved in facilitating activities of Islamist terror groups in India by supporting their cross-border movement and providing them with funds and shelter in the country (Ibid).

Last not least, drug trafficking also poses a national security threat as it has an adverse impact on the society, economy, and polity of the country. Large scale availability of narcotics and drugs 
encourages demand for narcotics and drugs by the domestic population. Consumption of drugs and narcotics destroys social mores and produces dysfunctional behaviour in the society thereby creating law and order problems in the country. As more and more people become addicted to narcotics, it causes a huge economic drain to the country through the loss of production and diversion of resources for caring and rehabilitation of the drug addicts, etc. (Manwaring, 1994). Drug trafficking also has a direct bearing on the political process as drug cartels subvert, penetrate and further corrupt state institutions to control the illegal drug trade.

\subsection{Trends of Drug Trafficking in India}

India has been a traditional consumer of opium and cannabis derivatives like ganja, bhang, hashish, etc. Earlier most of the demand was met locally with only a fraction of them being smuggled from Nepal and Pakistan. Since the quantities of the narcotics being smuggled in were less, it did not raise any alarm in the political establishment of the country. It was only with the largescale inflow of heroin and hashish from the AfghanistanPakistan-Iran region in the 1980s and its widespread disastrous consequences that drug trafficking became a major cause of concern. In subsequent decades, largescale availability of synthetic and medical drugs added a new dimension to the drug trafficking problem of the country. The following section analyses the trend in the trafficking of various narcotics, synthetic drugs and precursor chemicals in India and describes the routes through which these drugs and narcotics are trafficked in and out of the country. Trends of drug trafficking arederived by assessing the amount of narcotics and drugs which have been seized by various agencies over the years.

\subsection{Heroin and Brown Sugar}

As mentioned earlier, being closer to the Golden Crescent and Golden Triangle, India has been vulnerable to the trafficking of narcotics and drugs produced in these areas. Heroin was first trafficked into India in the mid-seventies from the Golden Triangle, which picked up by eighties. However, the quantity of trafficked heroin through the India-Myanmar border into the Northeast has always been very small as it is meant for local consumption only. India witnessed a 
large scale of trafficking of heroin in the early eighties when traffickers started rerouting heroin from the Golden Crescent through India instead of the Balkan route which was closed because of the Iran-Iraq war. Thus, between 1983 and 1988, the amount of heroin seized in India increased from about $100 \mathrm{~kg}$ to $3,029 \mathrm{~kg}$ (Narcotics Control Bureau, n.d).

Significantly, the end of the war in August 1988 lead to the reopening of the Balkan route and consequently heroin trafficking into India also registered a decline. For instance, in 1989 the amount of heroin seized was $2,714 \mathrm{~kg}$, which reduced drastically to $622 \mathrm{~kg}$ in 1991 (Ibid). Since then, the seizure figures of heroin remained constant at an average of around $1000 \mathrm{~kg}$ per year till 2007 with few dips corresponding with Kargil War and Operation Parakarm. In fact, between 2007 and 2011, heroin seizures have dipped substantially but by 2012 heroin trafficking again registered an increasing trend (See Table no. 1). The fact that the maximum amount of heroin was seized from Punjab in 2015 reinforces the fact that heroin is trafficked into the country from the Golden Crescentona large scale (Narcotics Control Bureau, 2016).In addition to the heroin that is trafficked into the country from the Golden Crescent and Golden Triangle, low-grade heroin called Brown Sugar is manufactured into the country by illegally diverting a substantial amount of licit opium as well as illicitly grown poppy. This lowgrade heroin is then trafficked inside the country as well as to the neighbouring countries, especially Nepal, Bhutan, Bangladesh, and Myanmar through roads as well as air.

Table no. 1: Heroin seized in the country

\begin{tabular}{cr}
\hline Year & Quantity (in kg) \\
\hline 2006 & 1182 \\
2007 & 1182 \\
2008 & 1063 \\
2009 & 1047 \\
2010 & 766 \\
2011 & 528 \\
2012 & 1033 \\
2013 & 1450 \\
2014 & 1370.78 \\
2015 & 1416 \\
\hline
\end{tabular}




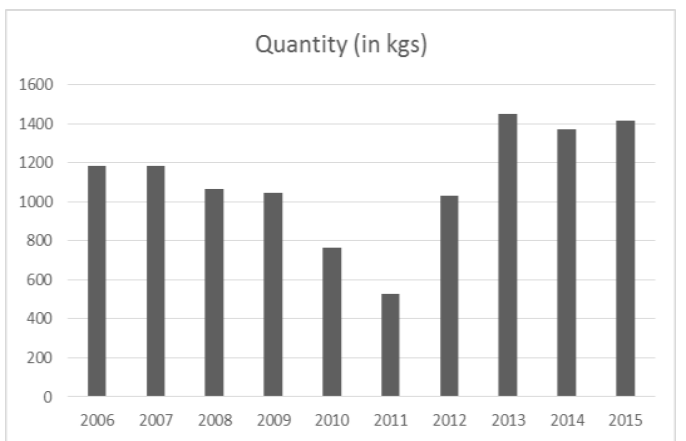

Source: Annual Report 2015-16. Narcotics Control Bureau, Government of India, New Delhi $(2016$, p. 9)

As mentioned earlier, heroin is trafficked into India from the Golden Triangle and Golden Crescent through the India-Myanmar and IndiaPakistan land borders respectively. Raging insurgencies and strong trans-border ethnic linkages coupled with a poorly guarded international border have facilitated trafficking of heroin through the India-Myanmar border. Incidentally, 90 percent of the heroin which is trafficked through the border is through four routes that enter into Manipur at four points- Moreh, Behiang, New Somthal and Kamjong from Myanmar (Chouvy, 2011). Heroin is also trafficked through Mizoram, Nagaland and Arunachal Pradesh.

Similarly, Sikh and Kashmiri militancy, pre-existing smuggling network and ideal terrain for hiding consignment along the border have made India-Pakistan border vulnerable to heroin trafficking. The Thar Desert and the riverine areas along the border in Punjab are being used for pushing in heroin into the country. Besides, the two trains that ply between India and Pakistan-the Samjhuata Express and the Thar Express have also been exploited for trafficking heroin. Trafficking of heroin along the India-Pakistan border is largely carried on by an array of cartels such as the DCompany, the Nigerian, the Afghan and the Kenyan syndicates who work in conjunction with each other. In a typical case, heroin is smuggled into India through Pakistan by the land or air routes by Afghan couriers. In many instances, farmers, villagers, and passengers are also induced to function as couriers for trafficking heroin into India. 
Once the consignment reaches Amritsar, Jaipur or Delhi, it is handed over to the Nigerian or Kenyan syndicate, who then traffic it out of the country through the air routes to international markets like the USA, Canada, and Europe (The Hindustan Times, 2016). These syndicates also use the courier and postal services to smuggle heroin out of the countries. Recent investigations have also revealed that drug traffickers are increasingly using the darknet and Bitcoin for buying and selling drugs and narcotics (Newsbtc, 2016). Brown sugar is trafficked to major metros in India especially Delhi, Mumbai, Kolkata, Chennai and Bengaluru by drug peddlers. Brown Sugar is also trafficked to Nepal, Bhutan, and Bangladesh through the land borders as well as through air routes.

\subsection{Hashish and Marijuana}

According to the United Nations Office on Drug Control (UNODC), "cannabis is the most widely abused illicit substance in the world"(Narcotics Control Bureau, 2016). Hashish and marijuana or ganja are the two derivatives of Cannabis which are extensively trafficked in India as well as in the world. Hashish has been traditionally trafficked into India from Nepal and therefore, Nepal remains a major source of hashish in India. Seizure figures indicate that the share of Nepalese hashish has steadily increased in the eighties from 7.2 percent in 1986 to 16.6 percent in 1989 (Narcotics Control Bureau, 1990). In the 1990s, as trafficking of hashish from Pakistan decreased, the share of Nepalese hashish trafficked into India increased substantially from 29.5 percent in 1991 to 40 percent in 2000 (Narcotics Control Bureau, 2001). This trend continued in the succeeding decade as well. However, in recent years the share of hashish from Nepal has reduced and in 2015 it stood at 21.95 percent (Narcotics Control Bureau, 2016). In addition to Nepal, the Golden Crescent has also been a major source of hashish in India, especially during the eighties. 
Table 2: Hashish seized in the country

\begin{tabular}{rr}
\hline Year & Quantity (in kgs) \\
\hline 2006 & 3,852 \\
2007 & 5,181 \\
2008 & 4084 \\
2009 & 3,549 \\
2010 & 4,300 \\
2011 & 3,872 \\
2012 & 3,385 \\
2013 & 4,407 \\
2014 & 2,280 \\
2015 & 3,349 \\
\hline
\end{tabular}

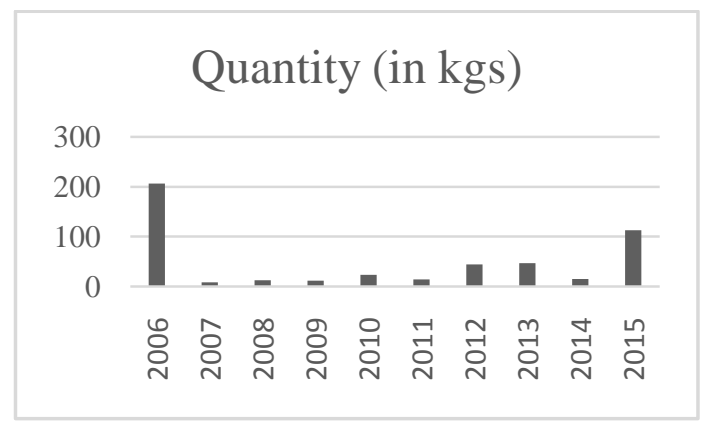

Source: Narcotics Control Bureau (2016, p. 13).

Hashish is primarily smuggled from Nepal into India through the well-developed road networks passing through mainland custom stations along the open border. Thus, Raxual, Rupaidiha, and Nautanwa have become major routes through which hashish is trafficked into India (BBC News, 2013). Hashish from AfghanistanPakistan-Iran was trafficked into India through the India-Pakistan international border. Incidentally, a large quantity of the hashish that is trafficked into India transits the country for destinations such as Europe, Canada and the United States of America.

Like hashish, Nepal has also been a major source of marijuana or ganja in India. Large quantities of marijuana/ganja have been trafficked into India from Nepal for decades. However, over the past few years, the share of marijuana or ganja of Nepalese origin in the Indian illegal drug market has reduced as demand for 
marijuana or ganja in India is being met through local production, especially in the states of Odhisha, West Bengal, Chhattisgarh and, Nagaland (Narcotics Control Bureau, 2016). It is believed that the Maoists have started illegal cultivation of cannabis in large tracts in Odhisha and Chhattisgarh as a source for funding their movement. Seizure figures of marijuana or ganja over the years have shown that its production and trafficking has remained more or less constant. However, statistics reveal that trafficking of marijuana or ganja has been declining since 2012 with the exception of 2014 (See Table no. 3).

Table 3: Marijuana or Ganja seized

\begin{tabular}{rr}
\hline Year & Quantity (in kgs) \\
\hline 2006 & 157,710 \\
2007 & 107,881 \\
2008 & 103,211 \\
2009 & 208,764 \\
2010 & 173,128 \\
2011 & 122,711 \\
2012 & 77,149 \\
2013 & 91,792 \\
2014 & 108,300 \\
2015 & 94,403 \\
\hline
\end{tabular}

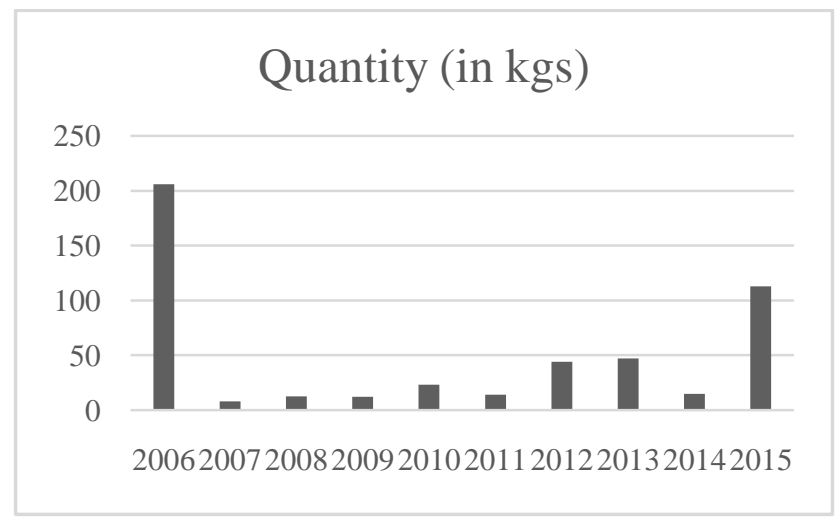

Source: Annual Report 2015-16. Narcotics Control Bureau, Government of India, New Delhi, 2016, p. 11.

As far as trafficking of marijuana or ganja is concerned, the bulk of it is trafficked by surface transport. Marijuana grown in the Northeastern states are transported to neighbouring countries such 
as Myanmar and Bangladesh through the poorly guarded international borders. In the rest of the country, trafficking of marijuana takes place through the India-Nepal border to Uttar Pradesh, West Bengal, Odisha, and Andhra Pradesh (Ibid).

\subsection{Cocaine}

Trafficking of cocaine into India is comparatively new and is a result of the diversification of cocaine markets. Presently, cocaine produced in Columbia, Peru, and Bolivia travels to India through West Asia and Gulf Countries (The Guardian, 2015). Trafficking trend of cocaine in India is characterised by small seizure amounts (See Table no. 4), although the cases against cocaine trafficking have increased manifolds. Cocaine is trafficked by concealing it inside parcels along with common household items such as cosmetics, utensils, books, etc. The new trend in cocaine trafficking is smuggling it in liquid form.

Table 4: Cocaine seized in the country

\begin{tabular}{lr}
\hline Year & Quantity (in kgs) \\
\hline 2006 & 206 \\
2007 & 8 \\
2008 & 12.46 \\
2009 & 12 \\
2010 & 23 \\
2011 & 14 \\
2012 & 44 \\
2013 & 47 \\
2014 & 14.68 \\
2015 & 113 \\
\hline
\end{tabular}

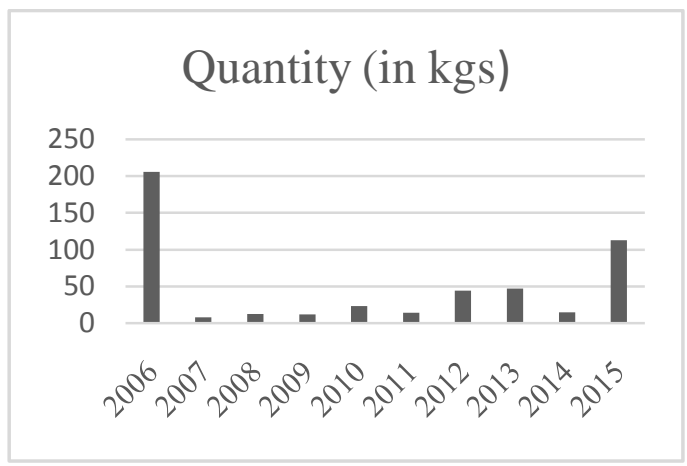

Source: Narcotics Control Bureau (2016, p. 16). 
As regards its trafficking trend is concerned, it is trafficked into India by African drug cartels. Investigations have revealed that in many instances drug cartels induce first-timers as well as old and terminally ill patients coming to India for medical treatments to smuggle cocaine into India. Cocaine is trafficked into India mainly through primary and secondary airports. The most important routes through which cocaine is trafficked into the country are the New Delhi-Addis Ababa-Lagos, and Mumbai-Lagos, others are New Delhi-Kathmandu, Chennai-Kuala Lumpur and HyderabadKuala Lumpur. Trafficking routes for East and South East Asian markets are Chennai-Kuala Lumpur, Hyderabad-Kuala Lumpur, Chennai-China, New Delhi-Hong Kong and New Delhi-Macao (Das, 2012).

\subsection{Synthetic Drugs}

India has witnessed a significant rise in the use of psychotropic substances and medicinal preparations containing codeine among addicts since late 1990. Stringent narcotics and drug laws, the rising price of heroin and easy availability are some of the factors which propelled a shift in the consumption pattern towards synthetic drugs and hence their trafficking in the country (Ibid). Some of the frequently abused synthetic drugs are Amphetamine Type Stimulant (ATS), Methamphetamine, Methaqualone, Alprazolam, Diazepam, Buprenorphine, Ketamine, Mephedrone, etc. (Narcotics Control Bureau, 2016).

ATS and methamphetamine are produced in large numbers in Southeast Asia especially in the Golden Triangle, which is then trafficked into India through the porous India-Myanmar international border. For instance, in 2015, anti-narcotics agencies have seized 10, 300 Nos., and 6800 Nos. of methamphetamine tablets in Imphal and Guwahati respectively (Ibid). Pharmaceutical preparations containing dextropropoxyphene and codeine are trafficked to the neighbouring countries especially to Nepal, Bhutan, and Myanmar. Seizures of codeine-based tablets and syrups originating from India have been reported periodically from both the countries (International Narcotics Control Bureau, 2010). Phensedyl, a codeine-based cough syrup, in particular, has become the item for smuggling into Bangladesh. Truckloads of phensedyl 
bottles from the factory are diverted to the Northeast and West Bengal by distributors and stockists for this purpose. In addition, empty phensedyl bottles are refilled with higher narcotic content and repackaged as 'phensedyl plus' and smuggled back into Bangladesh (Jain, 2006). The bulk of phensedyl bottles are smuggled into Bangladesh through the Kailashar (Tripura) and the Cachar-Karimganj (Assam) borders (Hmar In, 2011).

Ketamine is yet another medicinal preparation that is being smuggled out of India. Ketamineover the years has become a popular party drug especially in Southeast Asia and Europe. As a result, Ketamine is smuggled out to Southeast Asian and European countries as well as some African countries from the country after a substantial amount of the drug is diverted illegally from legitimate sources. Ketamine is smuggled in courier parcels and by concealing it among luggage and cargoes (Narcotics Control Bureau, 2016).

India is also a major source for Ephedrine and Pseudo-ephedrine used for manufacturing ATS as well as acetic anhydride used for the manufacturing of heroin. These chemicals are smuggled out of the country through the land as well as sea routes to the golden crescent and golden triangle where a number of laboratories are set up for the manufacturing of ATS and heroin. Seizures of ephedrine and pseudo-ephedrine indicate an increasing trend of trafficking of these chemicals from India to Myanmar. For instance, in 1999 1,421 $\mathrm{kg}$ of ephedrine was seized, which increased to 2,304 kg in 2003 and then further increased to 6,655 $\mathrm{kg}$ in 2011 (Ibid). It is reported that a majority of these seizures are related to consignments destined for Myanmar.

\section{Response to Drug Trafficking}

According to the World Drug Report of 2010, there were 871,000 heroin users and 674,000 opium users in India in 2008. In a survey conducted by the Ministry of Social Justice and Empowerment, in 2001, there were 2 million opium users and 8.7 million cannabis users.However, the trend and pattern of narcotics and drug consumption over the years had shown significant shifts. For instance, while the component of opium use among the drug addicts has been decreasing from 23.1 percent in 1997 to 9.2 percent 
in 2000, the share of cannabis has been increasing incrementally from 5.7 percent to 9.4 percent. The share of heroin has also witnessed an increase from 12.7 in 1997 to 18.5 percent in 1999. Most interestingly the component of other psychotropic drugs has increased from $16.2 \%$ to $23.2 \%$ between 1997 and 2000 (United Nationas Office of Drugs and Crime, 2010).

The exploitation of the trafficking routes with the help of wellentrenched criminal networks by terrorists to infiltrate with arms and explosives adds a critical dimension to the security of the borders. Composite seizures of drugs and arms by security forces at the borders, especially along the borders with Pakistan demonstrate a close nexus between drug traffickers and antinational elements. Given these challenges, protecting the borders against violations by either traffickers or terrorists becomes critical. At the same time, reducing the demand for drugs in domestic markets is also essential. Towards this end, India has adopted a comprehensive approach to reducing supply as well as demand for narcotics and drugs. The approach comprises four elements; enacting legislation; ensuring the physical security of the borders and coasts; eliciting cooperation from neighbours, and co-opting voluntary organisation in the national endeavour to prevent abuse of narcotics and synthetic drugs.

\section{Legislation}

For reducing the supply and demand for drugs into the country, the government deemed it necessary to enact a domestic law that would be stringent enough to deter the organized gangs of drug smugglers; that would allow concerned agencies to investigate and prosecute drug-related offenses; that would strengthen the existing control over drug abuse and; that would enable India to fulfill its obligations towards international treaties and conventions against narcotics drugs and their trafficking that it has signed (The Narcotic Drugs and Psychotropic Substances Act, 1985).

Accordingly, the Narcotics Drugs and Psychotropic Substances Act (NDPS) was enacted in 1985. Under this act, cultivation, manufacturing, transportation, export, and import of all narcotics drugs and psychotropic substances is prohibited except for 
medicinal and scientific purposes and as authorized by the government. The Act provides for rigorous punishment for a person violating this act and if s/he is caught peddling drugs for the second time, the death penalty could be awarded to the offender (The Narcotic Drugs and Psychotropic Substances Act, 1985). Under the NDPS Act, a number of persons have been persecuted and sentenced to rigorous imprisonment and their properties have also been confiscated. In fact, in a number of cases, special courts have served death penalties to persons found guilty of possessing drugs for the second time.

In addition, the government of India has also enacted the Prevention of Illicit Traffic in Narcotic Drugs and Psychotropic Substances Act in 1988, which allows the detention of persons suspected to be involved in the illicit trafficking of drugs (The Prevention of Illicit Traffic in Narcotic Drugs and Psychotropic Substances Act, 1988). Besides, few sections of the Customs Act of 1962 are implemented for curbing the illicit export of precursor chemicals. Under the Act, acetic anhydride has been declared as 'specified item' to check its illegal export and detection in the border states of Arunachal Pradesh, Nagaland, Manipur, and Mizoram. Also, a $100 \mathrm{~km}$ belt along the Myanmar border in these states has also been declared as 'specified area' under the Customs Act of 1962 to curb any illegal export of acetic anhydride (Shah, 1998). However, the mere enactment of laws is not enough. For combating drug trafficking, it is necessary to successfully investigate and prosecute drug-related offenses. Furthermore, proper licensing and strict vigilance is required to ascertain that there is no illegal cultivation of poppy and cannabisor diversion of drugs and chemicals.

\section{Physical Security of the Borders and Coasts}

Considering that India has been a transit hub as well as a destination for drug trafficking, the emphasis has been laid upon ensuring the security of the borders by preventing the easy ingress and egress of the drug traffickers along with their consignments through the borders. In this respect, the most visible measure that was undertaken was the building of the border fence. Border fences were erected first along the borders with Pakistan beginning in the 14 
mid-1980s when a large number of terrorists as well as huge quantities of drugs from Pakistan began to enter India. In later years, fences were built along the India-Bangladesh border primarily to prevent illegal migration, but these fences also acted as a barrier for the free movement of drug traffickers (Ministry of Home Affairs, 2016). That the construction of fences has reduced the inflow of drugs from across the borders substantially is corroborated by the reduced seizure figures as well as the increased use of sea routes by the traffickers to smuggle in drugs into the country. Strengthening surveillance along the borders by deploying adequate numbers of border guarding personnel is another measure undertaken to ensure the security of the borders. Regular patrolling and electronic surveillance is carried out for detecting suspicious movements along the borders as well as to gather intelligence to effectively deal with drug trafficking.

In addition to border guards, personnel from several central organizations such as the Customs, the Directorate of Revenue Intelligence, the Narcotics Control Bureau, and the Central Bureau of Narcotics as well as state organizations such as state police, state excise and state forest are also employed for detection and apprehension of drug consignments along the borders. Border states which have been witnessing increasing trends of drug trafficking have initiated several steps to deal with it. For example, Manipur has established a special police wing, the Narcotics and Affairs of Border, in 1985, whose primary focus is to prevent drug trafficking in the state (Manipur Police). Since the bulk of drugs are smuggled in through formal trading routes, India has embarked upon a plan to upgrade 13 of the land custom stations into integrated check posts (Ministry of Home afairs, 2016). with state of the art equipment to detect drug consignments being smuggled into and out of the country along with regular goods. The capacity to detect drug consignments at the airports and seaports has been strengthened by installing sophisticated screening and detection machines.

Despite these measures, it has not been possible to prevent the entry and exit of drugs across the borders because of various reasons. Firstly, prevention of drug trafficking is no more a priority issue for the government. It appears that somehow the government 
has been lulled by the belief that the consumption of drugs as well as their trafficking has declined in the country substantially as compared to those during the 1980s. This belief has also been reinforced by the near-constant quantities of drugs being seized by various agencies in the last few years. As a result, there does not seem to be urgency by the border guarding forces in apprehending drug consignments and peddlers from across the borders (Interview, 2012). Corruption in various concerned agencies has been one of the most difficult hurdles in the prevention of drug trafficking. Drug trafficking generates enormous profits and the lure of money has always been too difficult to resist. It is been alleged that officials not only take bribe from traffickers to look the other way when a drug consignment is trafficked but some of them are also actively involved in drug trafficking (The Times of India, 2009).

These difficulties prove that more than often unilateral approach is not adequate to address the problem with global dimensions and therefore, there is a need to seek the active support of the neighbours through a cooperative framework.

\section{Cooperation with Neighbours}

Realising the importance of a cooperative framework for the prevention of illicit trafficking of drugs and chemicals, India has entered into bilateral and multilateral agreements with several countries including neighbours (Narcontrol, 2011). Bilateral agreements were signed with Afghanistan (1990), Bangladesh (2006), Bhutan (2009), Myanmar (1993), and Pakistan (2011). These agreements have been instrumental in establishing a mechanism for mutual exchange of information and operational and technical experience, cooperation for joint investigations and other assistance 'to identify, suppress and prevent criminal activities of the international syndicates engaged in the illicit traffic of narcotics drugs, psychotropic substances and precursor chemicals' (Narcontrol, 2011). Additionally, there are several other bilateral institutional mechanisms that facilitate interactions between India and its neighbours to discuss the problem of drug trafficking. These interactions are held at national, sectoral and local levels on the annual, bi-annual and quarterly basis involving the Home 
Ministers and Home Secretaries, the heads of apex Drug Law Enforcement agencies and Director Generals of the Border Guarding Forces of India and its neighbours.

As for multilateral agreements with neighbours, India is a signatory to the SAARC Convention on Narcotics Drugs and Psychotropic substances, 1993. The convention provides for regular meetings of Home Ministers and Home Secretaries of the member countries as well as for interactions among the members of SAARC Conference on Cooperation in Police matters (Annual Report, 2009). India has also signed the BIMSTEC Convention on Cooperation in Combating International Terrorism, Transnational Organized Crime and Illicit Drug Trafficking in 2009 (Taw, 2009), which provides for a legal framework to all the member countries to combat drug trafficking and organized crime. India is also a party to the Pentalateral Cooperation on Drug Control, which focuses on the prevention of illicit trade of precursor and other chemicals used for the manufacture of heroin (Pentalateral Cooperation on Drugs, n.d).

Furthermore, India signed has Memoranda of Understanding on Narcotics Drugs related matter with Bhutan, Indonesia, Iran, Oman, USA, and Pakistan. India has also established Joint Working Groups on Counter-Terrorism with 27 countries wherein drugrelated offenses are discussed. India also interacts with the Drug Liaison Officers of several countries stationed in South Asia for sharing intelligence, conducting joint operations/investigations and for controlled deliveries. India has also been participating in various conferences, interactions, and meetings such as Commission on Narcotics Drugs, Asia-Pacific International Drug enforcement Conference, Regional International Drug Enforcement Conference, Anti-Drug Liaison Officials' Meeting for International Cooperation, CPDAP National Drug Focal Points Meetings, etc. that are organised to discuss various drug trafficking related matters (Narcotics Control Bureau, 2016).

While such bilateral and multilateral platforms provide opportunities for countries fighting drug trafficking to augment their capacities by sharing information, conducting joint operations and assisting one another in investigation and prosecution of any drug related crime, the fact remains that these platforms have not 
been able to achieve their desired objectives because of mutual distrust, hostilities, blame game and petty politics among member states. Political instability and lack of competence among the law enforcement and intelligence apparatus of the member countries to effectively counter drug trafficking also contribute to the failure.Besides, the SAARC Drug Offence Monitoring Desk (SDOMD), which was constituted in 1992 for creating a database about all major drug offenses with an aim to improve drug interception capabilities, has not proven effective given that information and intelligence shared by neighbouring countries are alleged to be of inferior quality (Narcotics Control Bureau). This underlines not only the indifferent attitude but also a lack of competence among the security and law enforcement personnel in some of the neighbouring countries.

\section{Co-opting Voluntary Organisations}

Since de-addiction and rehabilitation of drug dependants require innovative and sustained involvement, the government is assisted by a number of voluntary organizations. These voluntary organisatons complement the government's efforts in the prevention and control of drug abuse by spreading awareness about the destructive effects of drugs in the communities, as well as assisting in de-addiction treatments and reintegration of drug dependants into the societal mainstream. Since these NGOs have the required expertise and ground knowledge about drug abuse, they advise and work closely with governments.

Under Scheme of Assistance for Prevention of Alcoholism and Substance (Drug) Abuse, the Central government provides substantial financial assistance to voluntary oganisations for setting up of Integrated Rehabilitation Centres for Addicts, Training Centres, and Awareness Programmes (Ministry of Social Justice and Empowerment, n.d). The Federation for Indian NGOs (nongovernmental organisations) in Drug Abuse Prevention (FINGODAP) facilitates intense interactions among various NGOs to share their expertise and ensure better service for the reduction of drug dependency. These voluntary organizations, through various programmes like detoxification and de-addiction, rehabilitation and reintegration, outreach, awareness and 
education, sensitization and intervention, extended care and livelihood generation, have been quite effective in reducing the demand and abuse of drugs in the country.

\section{Conclusion}

India has been enduring the scourge of drug trafficking for three decades. The trends and patterns of drug trafficking in the country demonstrate that there is a gradual shift from traditional/natural drugs towards synthetic drugs that are being trafficked and consumed in the country. In the 1980s, a large quantity of heroin and hashish was smuggled in from the source areas into the country through various borders. While these drugs are still trafficked, albeit, in lesser quantities, the share of synthetic drugs such as ATS and codeine based pharmaceutical preparations has gone up tremendously. Various studies and newspaper reports indicate that drug consumption and trafficking are in fact showing an increasing trend.

To deal with the problem of drug trafficking and to protect the country's borders against such infringements, India has employed a mix of measures. On one hand, it has enacted stringent anti-drug laws, co-opted various voluntary organizations and sought to strengthen the physical security of its borders by various means, on the other hand, it has also been seeking the cooperation of its neighbours and other countries through several bilateral and multilateral agreements. These efforts have only been partially successful in dealing with the problem. For achieving greater success in preventing drug trafficking, few suggestions are forwarded:

- Prevention of drug trafficking has to be accorded greater priority. Special measures need to be formulated to check trafficking of drugs through the borders.

- Information/intelligence gathering regarding drug trafficking, its analysis and dissemination capabilities need to be strengthened.

- The issue of corruption in the border guarding forces as well as in other concerned agencies has to be dealt with in a 
pragmatic manner. While officials found guilty of drug trafficking should be punished severely, suitable reward systems should also be introduced to incentivise personnel to work diligently towards preventing drug trafficking.

- A database on production, trade and consumption of various drugs at the national level needs to be prepared to ascertain the extent of the problem.

- Agencies such as the SDOMD should be reinvigorated. Capacity building of personnel involved in the prevention of drug trafficking in India and its neighbouring should be enhanced.

- Above all greater cooperation with neighbours on matters of drug trafficking needs to be forged.

\section{References}

Central Sector Scheme of Assistance for Prevention of Alcoholism and Substance (Drugs) Abuse fort Social Defence Services (effective from 01.01.2015). Ministry of Social Justice and Empowerment, Government of India. Retrieved from http://socialjustice.nic.in/ SchemeList/Send/42?mid=48565 (Accessed on October 16, 2016)

Chhina, G. S. (2016, January). Nigerians top list of foreigners held for drug trade: Police. The Hindustan Times. Retrieved October 14, 2016 from http://www.hindustantimes.com/punjab/nigerians-top-list-offoreigners-held-for-drug-trade/storySOLKKcOAxlnXU8oqbBGKKI.html

Chouvy, P. A. (2010). Opium: uncovering the politics of the poppy. Harvard University Press.

Das, P. (2012). Drug trafficking in India: A case for border security. IDSA Occasional Paper No. 24, 37-38.

Das, P. (2012). Interview with senior BSF and NCB officials at New Delhi.

DNA. (2009, February). ATS arrests two cops for drug trafficking. DNA.Retrieved October 14, 2016 from http:// www.dnaindia.com/ india/report_ats-arrests-two-cops-for-drug-trafficking_1234928

Ethirajan, A. (2013, April). Nepal steps up battle against drug trafficker.BBC News. Retrieved October 13, 2016 from http:// www.bbc.com/news/business-21963600 
Extent, Pattern and Trend of Drug Use in India. (2004). Trend of Drug Use in India. Ministry of Social Justice and Empowerment, Government of India.

Farooqui, S. (2015, October). India becomes cocaine trafficking centre as drug flows rise of rich. The Guardian. Retrieved from https:// www.theguardian.com/global-development-professionals-network/ 2015/oct/01/india-cocaine-trafficking-drugs-rich-economic-growth.

Gautham. (2016, July). First instance of bitcoin and darknet based drug trafficking detected in India. Newsbtc. Retrieved October 14, 2016 from http:/ / www.newsbtc.com/2016/07/17/ bitcoin-darknet-drugtrafficking-india/

Hafeez, M. (2009, January). Saji stole at least $40 \mathrm{~kg}$ heroin. The Times of India. Retrieved October 14, 2016 from http:/ / articles.timesofindia.indiatimes.com/2009-01-

28/mumbai/28014052_1_vicky-oberoi-ips-officer-saji-mohanclassique-club

Hmar In. (2011, July). Smuggling out of phensedyl bottles to Bangladesh. Retrieved January 17, 2012 from http://hmar.in/news/smugglingout-of-phensedyl-bottles-to-bangladesh

Jain, S.K. (2006). The spurious drug menace and remedy. Health Administrator, 19(1), 33.

Jamwal, N. S. (2001).Terrorist financing and support structure in Jammu and Kashmir. Strategic Analysis, 26(1), 143.

Kalyanaraman,S. (2010). India and the challenge of terrorism in the hinterland. Strategic Analysis, 34(5), 706-707.

Licit cultivation. Central Bureau of Narcotics. Government of India. Retrieved October 7, 2016http:/ /cbn.nic.in/html/operationscbn.htm

Manwaring, M. G. (1994). National security implications of drug trafficking for the USA and Columbia. Small War and Insurgencies, 5(3), 382-383.

Ministry of Home Affairs. (2009). Annual Report 2009, pp.53-54. New Delhi: Government of India.

Ministry of Home Affairs. (2016). Annual Report 2015-2016, p. 54. New Delhi: Government of India.

Narcontrol. (2011, March). Narcotics Control Bureau Vol. 1 (1). Ministry of Home Affairs: Government of India.

Narcotics and Affairs of Border. (2016). Manipur Police. Retrieved from http:/ / manipurpolice.org/nab.htm.

Narcotics Control Bureau. (1990). Annual Reports 1989 - 1990. New Delhi: Government of India. 
Narcotics Control Bureau. (2001). Annual Report 2000-2001. New Delhi: Ministry of Finance, Government of India.

Narcotics Control Bureau. (2016). Annual Report 2009. New Delhi: Government of India.

Otis, J. (2014).The FARC and Columbia's illegal drug trade. Wilson Centre, 3-4. Retrieved October 13, 2016 from https:// www.wilsoncenter.org/sites/default/files/Otis_FARCDrugTrade201 4.pdf

Paul, M. (2011, May). Tripura feeds Bangladesh drug demand.The Times of India. Retrieved October 14, 2016 from http:/ / articles.timesofindia.indiatimes.com/2011-05-25 guwahati/ 29581533_1_phensedyl-cough-syrup-bangladesh

Pentalateral Cooperation on Drugs. (2016, October). Retrieved from http://en.oncb.go.th/document/e1-coop-5L-idx.asp (Accessed on October 14, 2016).

Shah, G. R. (1998). In Encyclopaedia of Narcotics Drugs and Psychotropic Substances (Vol. III-Indian Initiatives), p. 888. New Delhi.

Shah, T., \& Mashal, M. (2016). Bountiful Afghan opium harvest yields profits for the Taliban. The New York Times. Retrieved October 13, 2016 from http://www.nytimes.com/2016/05/04/world/asia/talibanafghan-poppy-harvest-opium.html?rref=collection $\% 2 \mathrm{~F}$ timestopic \% 2FDrug\%20Trafficking\%20in\%20Afghanistan\&action=click\&contentC ollection=timestopics\&region=stream\&module=stream_unit\&version $=$ latest\&contentPlacement $=3 \&$ pgtype $=$ collection $\& \_r=0$

Shivananda, H. (2011). Nexus of drug trafficking and militancy exposed at New Delhi, IDSA Comment. Retrieved October 13, 2016 from http://www.idsa.in/idsacomments/NexusofDrugTraffickingandMili tancyExposedatNewDelhi_shivanandah_130411

Taw, N. P. (2009, December). Joint Statement of the Twelfth BIMSTEC Ministerial Meeting. Retrieved October 14, 2016 from http:// www.bimstec.org/12th_MM_details.html

The International Narcotics Control Board. (n.d). Annual Report 2010, p. 90. New Delhi: Government of India.

The Narcotic Drugs and Psychotropic Substances Act, 1985 (61 of 1985) (Ind.)

United Nations Office of Drug and Crime. (2010). World Drug Report 2010, p. 40. Vienna: United Nations Office of Drugs and Crime.

Unnithan, S. (2016). Pathankot or Mumbai 1993: corrupt officers sell India to terror. DailyO. Retrieved October 13, 2016 from http:// www.dailyo.in/ politics/pathankot-punjab-corruption-pakistan-1993mumbai-blasts-dawood-ibrahim/story/1/8380.html 
Unnithan, S., Aurora, B.V. (2013, November). Narco Nigerian. Indiatoday.in. Retrieved October 14, 2016 from http: // indiatoday. intoday. in/story/nigerians-drugs-narcotics-goa-police-drugtrafficking-nigerian-murder/1/326094.html

Vice, L.S., Shanta, S.A. S.N. (2001). Thapa and Ors. vs Union of India (Uoi) and Ors. Central Administrative Tribunal. Received October 13, 2016 https://indiankanoon.org/doc/948580/?type=print 